\title{
Announcing a new international journal
}

\section{Language Testing}

Editors: Arthur Hughes and Don Porter

Department of Linguistic Science, University of Reading

Advisory board: Charles Alderson (University of Lancaster) Lyle Bachman (University of Illinois) J.B. Carroll (University of North Carolina) David Crystal (University of Reading) Alan Davies (University of Edinburgh) Paul Fletcher (University of Reading) John W. Oller Jr (University of New Mexico) Bernard Spolsky (Bar-Ilan University) Douglas Stevenson (University of Essen) John Upshur (University of Michigan) Jon Miller (University of Wisconsin)

Language Testing will provide a forum for the exchange of ideas and information between people working in the fields of first and second language testing and assessment. These will include researchers and practitioners in English as a Foreign Language/English as a Second Language Testing, mother tongue testing, and assessment in child language acquisition and language pathology.

Each issue will contain major articles (including review articles), reviews of tests as well as of books, research reports, and correspondence. The editors are determined that no backlog of articles shall be allowed to develop - the keynote of the journal will be immediacy.

Articles for editorial consideration are welcome. Manuscripts or summaries of proposed articles should be submitted to Don Porter or Arthur Hughes, Department of Linguistic Science, University of Reading, Reading RG6 2AA.

Frequency: The journal will appear twice a year in June and December. The first issue is scheduled for June 1984.

Extent: The average length of each issue will be 128 pages.

One volume of two issues will be approximately 256 pages.

Annual subscription: Institutional $\$ 25.00$

Individual $£ 16.50$

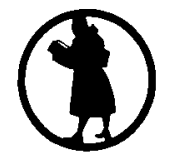

\section{Edward Arnold} 41 Bedford Square, London WC1B 3DQ 
Journal

of

Literary

Semantics

\section{An International Review}

ISSN 0341-7638
Editor: Trevor Eaton

Academic Headquarters:

Language Centre, University of Kent at Canterbury/England

The aim of the Journal of Literary Semantics is to concentrate the endeavours of theoretical and applied linguists upon those texts traditionally classed as 'literary' in the belief that such texts are a central, not a peripheral, concern of linguistics.

The journal publishes articles on all aspects of literary semantics; articles of a philosophical nature attempting to relate the study of literature to other disciplines, such as psychology, neurophysiology, mathematics, history; articles dealing with the educational problems inherent in the study of literature.

The journal will also publish reviews of books whose subject matter is germane to literary semantics. Books for review should be sent to the Editor.

J.L.S. appears in annual volumes, each volume consisting of three issues, appearing in April, August and October.

Subscription per volume

DM 64,-

Single copies

DM 27,-

Back volumes (Nos. $1-X$ )

Sole distribution

USA and Canada, Middle and South America: John Benjamins North America, Inc., Publisher, One Buttonwood Square, 202, Philadelphia/PA. 19130/USA

Southern Africa: Universitas Books (Pty.) Ltd., P.O. Box 1557, 0001 Pretoria, South Africa Australia: River Seine Publications Pty. Ltd., 132 Elgin Street, Carlton, VIC. 3053, Australia

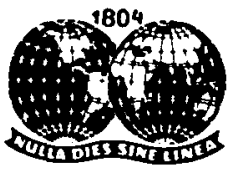

\section{JULIUS GROOS VERLAG Postfach 102423 - D-6900 Heidelberg 1}




\section{THE}

\section{BILINGUAL FAMILY}

\section{NEWSLETTER}

\section{Editor GEORGE SAUNDERS}

This new quarterly publication is being started in response to suggestions and requests from purchasers of George Saunders' bestselling book Bilingual Children: Guidance for the Family.

An extensive editorial advisory board has been appointed which is intended to cover all aspects of family bilingualism. The primary requirement in choosing members of this editorial board is that they should all be actively involved in a Family Bilingual Situation. In some cases this has turned out to mean that not only is the present generation of children being given a bilingual upbringing but also that one or both of the parents were themselves brought up in such circumstances.

It is envisaged that each issue of The Bilingual Family Newsletter will contain:

1. A fairly short main article, written for the general reader, but incorporating current research and thinking on bilingualism.

2. A second article by a member of the advisory board or another contributor relating their personal experiences.

3. A correspondence section where parents, and children, can exchange views.

4. A question and answer section in which members of the advisory board will suggest answers to reader's queries and problems.

The first issue of The Bilingual Family Newsletter will appear in February 1984 . There will be four issues a year and overseas subscribers will receive their issues by air.

Price f3.00 p.a. for individual family subscribers

LIBRARY SUBSCRIPTION $£ 4.50$ p.a.

Discounts are available for multiple subscriptions to one address 


\section{Language Teaching}

The international abstracting journal for language teachers and applied linguists

is indispensable for everyone concerned with the teaching and learning of foreign languages, including English as a second or foreign language:

* keeps readers up to date with a minimum expenditure of time and money

* offers comprehensive cover of the field in a compact and inexpensive form

* articles from nearly 400 journals from all parts of the world are selected and abstracted by experts

* international experience published in many languages is made accessible to an English-reading audience

* information about good practice in classroom teaching and effective language learning, as well as the latest research findings

\section{Published Quarterly}

\section{In every issue:}

* a state-of-the-art survey article on a major subject in language teaching

* more than 150 abstracts in English

* details of research projects in various counties

* sources of further information for in-depth study - bibliographies and annotations of recent publications

* subject and author indexes

\section{CAMBRIDGE UNIVERSITY PRESS}

The Pitt Building, Trumpington Street, Cambridge CB2 IRP 32 East 57 th Street, New York, NY 10022 